НАУКОВИЙ ВІСНИК

Ventife messenger of L Liv National University of

(1)

(x)

TIIT

1 is 1 if

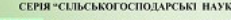

Науковий вісник Дьвівського національного університету ветеринарної медицини та біотехнологій імені С.3. Гжицького. Серія: Сільськогосподарські науки

Scientific Messenger of Lviv National University of Veterinary Medicine and Biotechnologies. Series: Agricultural sciences

UDC 636.2

\title{
Modern technologies of equipping of animal husbandry rooms
}

\author{
R. M. Myniv \\ Stepan Gzhytskyi National University of Veterinary Medicine and Biotechnologies Lviv, Ukraine
}

Article info

Received 03.02.2020

Received in revised form 03.03 .2020

Accepted 04.03.2020

Stepan Gzhytskyi National University of Veterinary Medicine and Biotechnologies Lviv, Pekarskaya Str., 50, Lviv, 79010, Ukraine. Tel.: +38-067-370-43-92 E-mail:muniv@ukr.net
Myniv, R. M. (2020). Modern technologies of equipping of animal husbandry rooms. Scientific Messenger of Lviv National University of Veterinary Medicine and Biotechnologies. Series: Agricultural sciences, 22(92), 56-61. doi: 10.32718/nvlvet-a9210

Modern technologies for the construction of livestock rooms, inexpensive foundations, short construction time, low material capacity of the building, the possibility of using a leasing payment scheme are factors that will minimize construction costs. At much lower initial cost, frame and awning livestock rooms pay off much faster than capital buildings, with the construction of livestock rooms cost 3-5 times cheaper. The standard hangar designs are versatile and versatile. The form determines the amount of working space inside the hangar, depending on the purpose of the operation. Width standard up to $30 \mathrm{~m}$. Length - proportional, step between arches $3 \mathrm{~m}$. They are: tent, arched and straight. Frame and awning hangars up to 1500 square meters. m. are considered to be high-speed mobile structures of temporary type. No permits are required for their construction. There is no need for the construction of the foundation, the involvement of large machinery. Despite the "temporary type" metal construction is reliable. Construction is carried out according to the developed design standards - SP 384.1325800.2018. If necessary, the awning membrane can be easily and quickly repaired or replaced with a new one after 10-15 years. The most effective way to insulate a hangar today is to insulate it by spraying polyurethane foam. Depending on the technological scheme of installation of equipment of livestock premises, the required number, size and location of the farm gate is determined. The ends of the livestock premises are equipped with swing gates for the entry of transport, distributing feed to the feeding table, the gates can be awning or metal, sectional, recoil or swing. At the request of the customer can be designed passages for pushing. In order to reduce electricity consumption for heating purposes and to save money on electricity, we propose to equip the heating system of frame and awning hangars with another source of heat supply - a heat pump. To reduce electricity costs for heating radiators, it is necessary to install thermostatic valves at the rate of one valve per radiator. The electric power of the heat pump with a minimum conversion factor (KP) will be $12.5 \mathrm{~kW}$. Electricity costs for circulation of such volume of a brine at resistance of $8 \mathrm{~m}$ make about 0,5 $\mathrm{kW}$. Energy savings when using a heat pump in monetary terms at an electricity tariff of 193.28 kopecks. without VAT for $1 \mathrm{~kW}$. year will be $59976 \times 193.28=115.922$ thousand UAH without VAT.

Key words: livestock premises, frame and awning hangars, heat pump.

\section{Сучасні технології облаштування тваринницьких приміщень}

\author{
Р. М. Минів
}

Львівський національний університет ветеринарної медицини та біотехнологій імені С. 3. Гжииького, м. Львів, Україна

Сучасні технологіі будівничтва тваринницьких примімень, недорогі фундаменти, короткий термін будівниитва, низька матеріаломісткість споруди, можливість використання лізингової схеми оплати - фактори, шуо забезпечать мінімізацію витрат на будівничтво. При значно нижчій первісній вартості каркасно-тентові твариннииькі примімення окупаються набагато ивидше порівняно з капітальними будівлями, при цуьому будівництво твариннищьких приміщень обходиться в 3-5 разів дешевще. Стандартні конструкиії ангарів універсальні і багатофункиіональні. Форма визначає кількість робочого простору всередині ангара залежно від иілей експлуатації. Ширина стандартна - до 30 м. Довжина - пропориійна, крок між арками 3 м. Вони бувають: иатрові, арочні та прямостінні. Каркасно-тентові ангари площею до 1500 кв. м вважаються швидкобудівними мобільними спорудами тимчасового 
типу. Для їх будівництва не потрібні дозвільні документи. Немає необхідності в зведенні фундаменту, залученні великогабаритної техніки. Незважаючи на “тимчасовий тип” металоконструкція надійна. Будівництво здійснюється згідно з розробленими проектними нормами - СП 384.1325800.2018. Тентову мембрану при необхідності легко і швидко відремонтувати або замінити на нову після 10-15 років. Найефективнішим способом утеплення ангара на сьогодні є утеплення за допомогою напилення пінополіуретану. Залежно від технологічної схеми установки обладнання тваринницьких приміщень визначається необхідна кількість, розмір і розташування воріт ферми. Ториі тваринницьких приміщень комплектуються розпашними воротами для в '̈зду транспорту, щуо роздає корми на відгодівельний стіл, ворота можуть бути тентові або металеві, секиійні, відкатні або розпашні. За бажанням замовника можуть бути спроектовані проходи для гноєвидалення. 3 метою зниження споживання електроенергії на потреби опалення, економіі коштівна електроенергію ми пропонуємо обладнати систему опалення каркасно-тентових ангарів іншим джерелом теплопостачання - тепловим насосом. Для зниження витрат електроенергї на опалення на радіаторах необхідно встановити термостатичні клапани з розрахунку один клапан на радіатор. Електрична потужність теплового насоса при мінімальному коефіцієнті перетворювання (КП) складе 12,5 кВт. Витрати електроенергї на циркулячію такого обсягу розсолу при опорі 8 м складають близько 0,5 кВт. Економія електроенергії при використанні теплового насоса в грошовому еквіваленті при тарифі на електроенергію 193,28 коп. без ПДВ за 1 кВт.год складе $59976 \times 193,28=115,922$ тис. грн без ПДВ.

Ключові слова: тваринницькі приміщення, каркасно-тентові ангари, тепловий насос.

\section{Вступ}

Будівництво швидко-монтованих каркаснотентових приміщень - один 3 найбільш оптимальних варіантів облаштування тваринницьких приміщень. Сучасні технології будівництва тваринницьких приміщень, недорогі фундаменти, короткий термін будівництва, низька матеріаломісткість споруди, можливість використання лізингової схеми оплати фактори, що забезпечать мінімізацію витрат на будівництво (Gasanova \& Kamilova, 2007; Fedorenko \& Sadov, 2012; Smirnov, 2013). Обмеження експлуатації каркасно-тентового корівника при врахуванні температури навколишнього середовища відсутні.

Сьогодні в Північній Америці: у Сполучених Штатах і Канаді існують десятки каркасно-тентових ферм, на яких одночасно перебувають від тридцяти до двохсот тисяч тварин. У цих місцях шість місяців на рік зима і морози до сорока градусів. Цей бізнес процвітає при тому, що вартість кормів і робочої сили набагато дорожчі, ніж в Україні.
За значно нижчої первісної вартості каркаснотентові тваринницькі приміщення окупаються набагато швидше порівняно 3 капітальними будівлями, при цьому будівництво тваринницьких приміщень обходиться в 3-5 разів дешевше.

Наприклад, терміни виготовлення металоконструкцій і тентового покриття тваринницьких приміщень площею 2000 м кв. - 40-45 робочих днів, монтажні роботи - до 30 днів. Роботи можуть проводитися заводом-виробником чи замовником при контролі виробника (шеф-монтаж).

\section{Результати та їх обговорення}

На ринку будівництва ангарів основна конкуренція складається між:

- безкаркасними ангарами арочного типу;

- каркасними конструкціями 3 накриттям 3 профлиста;

- каркасно-тентовими ангарами 3 накриттям 3 ПВХ мембрани.

Переваги і недоліки кожного типу наведено в табл. 1.

\section{Таблищя 1}

Порівняльна характеристика ангарів

\begin{tabular}{|c|c|c|c|}
\hline \multirow{2}{*}{ Критерії } & \multicolumn{3}{|c|}{ Характеристика ангарів } \\
\hline & Безкаркасний & Каркасний з профнастилу & Каркасно-тентовий \\
\hline Ціна & $\begin{array}{l}\text { Орієнтовна вартість будівництва від } \\
1000 \text { до } 1700 \text { грн/кв. м (по підлозі } \\
\text { споруди) }\end{array}$ & $\begin{array}{l}\text { Орієнтовна вартість від } 1700 \text { до } 2000 \\
\text { грн/кв. м (по підлозі споруди) }\end{array}$ & $\begin{array}{l}\text { Орієнтовна вартість від } 1400 \\
\text { до } 1800 \text { грн/кв. м (по підлозі } \\
\text { споруди) }\end{array}$ \\
\hline $\begin{array}{l}\text { Швидкість } \\
\text { будівництва }\end{array}$ & Реально за 2 тижні & Реально за 1,5 місяця & Реально за 1 місяць \\
\hline $\begin{array}{l}\text { Ймовірність } \\
\text { протікання }\end{array}$ & $\begin{array}{l}\text { Ймовірність течі конструкції зале- } \\
\text { жить від дотримання технології } \\
\text { вальцювання. Випадки відшарування } \\
\text { i протікання листів безкаркасних } \\
\text { ангарів спостерігаються повсюдно }\end{array}$ & $\begin{array}{lcc}\text { Проблеми } & \text { течi } & \text { стосуються } \\
\text { найчастіше } & \text { 3'єднань } & \text { профлиста. } \\
\text { Через } & \text { перепад } & \text { температур } \\
\text { втрачається герметичність 3'єднань }\end{array}$ & 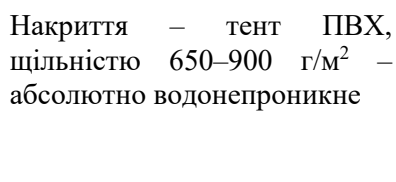 \\
\hline $\begin{array}{l}\text { Снігове } \\
\text { навантаження }\end{array}$ & $\begin{array}{l}\text { Сніг накопичується на верхній поло- } \\
\text { гій смузі. Обвалення ангара при } \\
\text { товщині снігового покриву від } 50 \text { см }\end{array}$ & $\begin{array}{l}\text { Для покрівлі ангара підходить проф- } \\
\text { настил } 3 \text { металу товщиною мінімум } \\
0,45 \text { мм }\end{array}$ & $\begin{array}{l}\text { Снігове навантаження - до } \\
180 \text { кгс/кв. м; } \\
\text { При ухилі від } 60 \text { градусів сніг } \\
\text { зісковзує на землю. }\end{array}$ \\
\hline $\begin{array}{l}\text { Світлопропускна } \\
\text { здатність }\end{array}$ & $\begin{array}{l}\text { Темно. } \quad \text { Вимагає } \quad \text { додаткового } \\
\text { освітлення в денний час доби }\end{array}$ & $\begin{array}{l}\text { Темно. } \quad \text { Вимагає додаткового } \\
\text { освітлення в денний час доби }\end{array}$ & $\begin{array}{l}\text { Приміщення не вимагає } \\
\text { додаткового освітлення } \\
\text { денний час доби }\end{array}$ \\
\hline Утеплення & $\begin{array}{l}\text { Двошарова конструкція } 3 \text { утеплю- } \\
\text { вачем посередині, утеплювач напи- } \\
\text { люють або “підшивають” зсередини } \\
\text { до одношарової конструкції }\end{array}$ & $\begin{array}{l}3 \text { середини пінопластом, піно- } \\
\text { поліуретаном, пензлем, мінеральною } \\
\text { ватою або сендвіч панелями зовні }\end{array}$ & $\begin{array}{l}\text { Варіант подвійний даху. Між } \\
\text { мембраною використовують } \\
\text { мінеральну вату }\end{array}$ \\
\hline
\end{tabular}

Джерело (Karkasnyi abo bezkarkasnyi anhar?) 
Стандартні конструкції ангарів універсальні й багатофункціональні. Форма визначає кількість робочого простору всередині ангара залежно від цілей експлуатації. Ширина стандартна - до 30 м. Довжина - пропорційна, крок між арками 3 м. Вони бувають такими:

- Шатрові: будівлі мають двоскатний дах та похилі стіни. За рахунок розширення стін донизу на $20^{\circ}$ збільшується корисна площа. Переваги: оптимальний розподіл навантаження від снігу завдяки двоскатному даху, зведення споруд будь-якого розміру, скорочені терміни будівництва.

- Арочні: напівкруглі конструкції 3 опорамидугами є найбільш стійкими. Площа та висота ангару залежить від радіусу та кількості арок. Завдяки такій формі вдається рівномірно розподілити навантаження на обшивку під час сильного вітру, снігопаду та дощу.

- Прямостінні: один із найпоширеніших видів каркасних ангарів. Відсутні обмеження за розмірами та кількістю поверхів. Найбільш економічно вигідний тип ангару. Вартість споруди залежить від їі розміру, типу фундаменту, використовуваних матеріалів та інших факторів. За необхідності можна провести утеплення ангару, організувати водопостачання, опалення та інші комунікації (рис. 1).

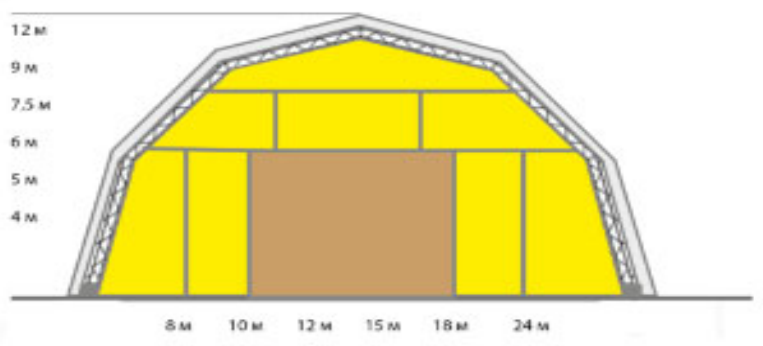

а. иатровий

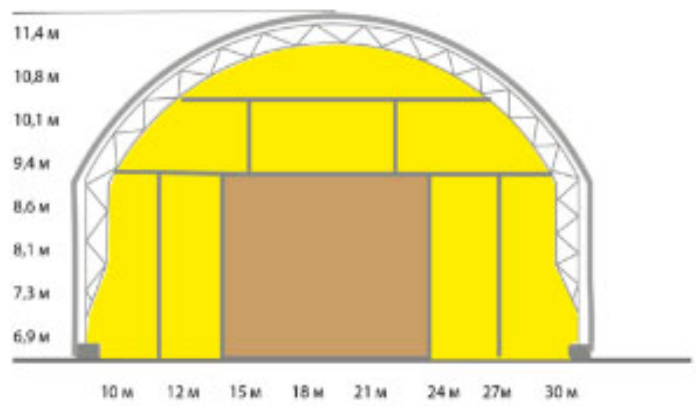

б. арочний

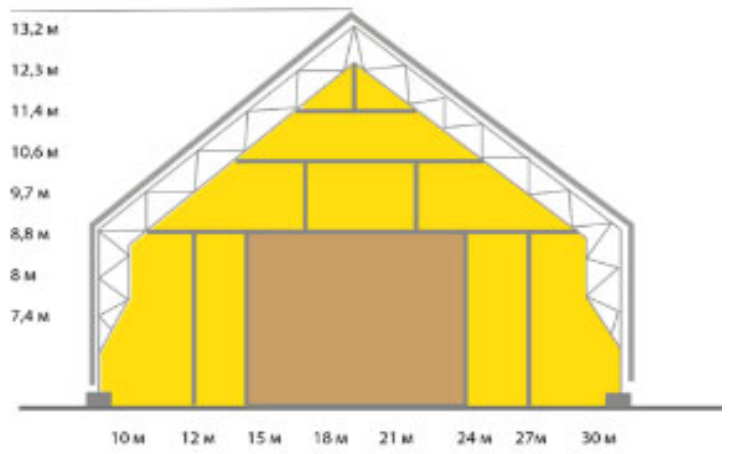

в. прямостінний

Рис. 1. Стандартні конструкції ангарів

Джерело (Budivnytstvo anhariv karkasno-tentovoho typu)
Каркасно-тентові ангари площею до 1500 кв. м вважаються швидкобудівними мобільними спорудами тимчасового типу. Для їх будівництва не потрібні дозвільні документи. Немає необхідності в зведенні фундаменту, залученні великогабаритної техніки. Замовник економить гроші та час на оформленні документації та підготовки до будівництва. Незважаючи на “тимчасовий тип”, металоконструкція надійна. Обробка металу антикорозійним складом і покриття порошковою фарбою забезпечує захист від іржавіння і руйнування. Будівництво здійснюється згідно з розробленими проектними нормами - СП 384.1325800. 2018. Тентову мембрану при необхідності легко i швидко відремонтувати або замінити на нову після 10-15 років.

Технологічний процес будівництва ангару складається з таких етапів:

1. Розробка проекту ангара з урахуванням призначення будівлі, поверховості, площі, регіону будівництва, будівельних нормативів i побажань замовника.

2. Зведення фундаменту. Фундамент може бути пальовий, стовпчастий або стрічковий залежно від розміру, призначення будівлі, кліматичних умов регіону будівництва, а також виду грунту.

Стовпчастий фундамент - використовується на твердих грунтах; монолітні залізобетонні плити 3 прямокутним перетином, заглиблені нижче лінії промерзання грунту.

Пальовий фундамент - загострені залізобетонні палі, з’єднані ростверком. Використовуються на грунтах із середньою несучою здатністю.

Стрічковий фундамент - залізобетонний на складному арматурному каркасі, незаглиблений. Використовується на грунтах 3 низькою несучою здатністю.

3. Металевий каркас. Несучий металевий каркас складається зі сталевих прокатних профілів, форма і товщина яких обирається залежно від розміру ангара, його призначення та навантаження. Монтаж колон на фундамент проводиться за допомогою закладних деталей і анкерних болтів, використовується подальша підлива бетону в основу. Між собою рами з'єднуються металевими або дерев'яними прогонами, які призначені для кріплення стінових і покрівельних конструкцій.

4. Огороджсувальні конструкції. Як правило, огороджувальні конструкції виконуються з профнастилу, банерного листа або сендвіч-панелей та тентового покриття. Залежно від призначення ангара вони можуть бути холодного типу (як огороджувальні конструкції використовується профнастил) або утепленими (в такому випадку огороджувальні конструкції можуть утеплятися полистовим способом - між двома рядами обшивки поміщається утеплювач).

Дуже складно рівномірно покрити всю поверхню ангара будь-яким теплоізоляційним матеріалом, що вимагає кріплення - завжди залишаються щілини i зазори, які значно знижують загальну ефективність всього теплоізоляційного шару. Та й тривають такі роботи дуже довго, адже практично завжди вони про- 
водяться на значній висоті, а це робочий час знову таки потрібно оплачувати.

Найефективнішим способом утеплення ангара на сьогодні $\epsilon$ утеплення за допомогою напилення пінополіуретану. Крім дуже високих теплоізоляційних показників цей спосіб утеплення володіє великою кількістю інших переваг, які ще виразніше видно при роботі зі значними обсягами і площами:

- Немає необхідності влаштування додаткового кріплення шару утеплювача до каркаса ангара - пінополіуретан має дуже високу адгезію до сталі і напилюється відразу на каркас.

- Методом напилення пінополіуретану можна отримати рівномірний шар без тріщин, зазорів і містків холоду.

- Пінополіуретан напилюється на поверхню будьякої конфігурації і форми, в тому числі на горизонтальні поверхні (можна утеплити стелю).

- Пінополіуретан має дуже низькою паропроникністю, що робить непотрібним пристрій додаткових шарів пароізоляції.

- Пінополіуретан довговічний - термін служби до 50 років.

- Роботи 3 утеплення ангара напиленням пінополіуретану за часом займуть в рази менше, ніж утеплення альтернативними матеріалами (1000 м² - від 2 днів).

- Утеплення складів шаром пінополіуретану 50мм аналогічно утепленню шаром в 150 мм мінеральної вати.

- При напиленні можна отримати будь-яку необхідну товщину шару, виходячи 3 очікуваного температурного режиму.

- Пінополіуретан екологічно чистий і не підтримує горіння.

- Невисока щільність матеріалу дозволяє уникнути додаткових навантажень на конструкцію (Uteplennia. Pinopoliurean).

Залежно від технологічної схеми установки обладнання тваринницьких приміщень визначається необхідна кількість, розмір і розташування воріт ферми. Торці тваринницьких приміщень комплектуються розпашними воротами для в'їзду транспорту, що роздає корми на відгодівельний стіл, ворота можуть бути тентові або металеві, секційні, відкатні або розпашні.
За бажанням замовника можуть бути спроектовані проходи для гноєвидалення.

Переваги тентових ангарів перед конструкціями інших типів:

- відносно невисока вартість порівняно 3 ціною традиційних споруд зі сталі, бетону, цегли та профнастилу;

- мобільність споруди, тобто можливість його повної перестановки в інше місце;

- відсутність необхідності проведення довгих і дорогих погоджень, тому що тентові конструкції належать до розряду тимчасових будівель і споруд;

- пожежобезпечність тентових споруд, зважаючи на виготовлення покриттів 3 матеріалів групи М2, тобто матеріалів, що не підтримують горіння;

- економія на фундаменті: метод зведення ангара відрізняється від традиційного на основі бетонної основи великою економічністю і швидкістю виробництва робіт;

- технологія дозволяє зводити ангари на звичайному дорожньому асфальтобетонному покритті,

- тент добре пропускає сонячне світло, тому в денний час не потрібно електричне освітлення - на відміну від металевих ангарів;

- у тентових ангарах, де утримуються тварини, сонячні промені вбивають бактерії, що створює здорову фітосанітарну обстановку;

- аміак, що виділяють тварини, не впливає на тент і оцинковані металеві конструкції. Ангари побудовані 3 профлиста, дерев'яної дошки і бітуму в тваринництві під впливом агресивних середовищ робляться непридатними набагато швидше, ніж тентові;

- зберігається сприятливіший температурний режим, ніж в металевих: влітку в них прохолодніше, а взимку тепліше, що важливо для тварин.

- монтуються набагато швидше, ніж капітальні 3 профлиста й інших матеріалів, їх можна досить швидко демонтувати і перенести в інше місце;

- тентові ангари відчутно дешевші, ніж 3 профлиста й інших матеріалів.

Техніко-економічні характеристики тентового покриття наведені в таблиці 2.

Таблиця 2

Характеристика тентового покриття

\begin{tabular}{ll}
\hline \multicolumn{1}{c}{ Показник } & \multicolumn{1}{c}{ Характеристика } \\
\hline Економія & Тентові покриття, завдяки своїй прозорості, пропускають всередину велику кількість природного \\
енергесурсів & світла. Каркасно-тентові конструкції вимагають в два рази менше штучного освітлення, ніж \\
& традиційні будівлі. Завдяки природному освітленню - незалежні від електричних мереж. Навіть у \\
& похмуру погоду в денний час не потрібно штучного освітлення. Для того, щоб забезпечити в \\
& будівлі з металевих конструкцій таке ж яскраве освітлення, як у каркасно-тентових, потрібні були \\
& б електричні лампи потужністю в кілька тисяч ват. \\
\hline Комфорт & Завдяки низькій теплопровідності покриття тенту служить свого роду бар'єром, що захищає \\
& повітря всередині будівлі від нагрівання під впливом сонячних променів. На відміну від метале- \\
& вих конструкцій, покриття тенту не пропускає тепло всередину приміщення. Білосніжне покриття \\
& не нагрівається, інгібітори ультрафіолетового випромінювання забезпечують захист від шкідли- \\
& вого впливу сонячних променів і продовжують термін експлуатації тенту. Каркасно-тентові конс- \\
& трукції мають більший внутрішній об'єм і вміщають більше повітря, завдяки чому тепле повітря \\
& піднімається під самий дах і, поступово піднімаючись до стелі, повністю залишить приміщення, а \\
& температура внизу приміщення залишається нижчою. \\
\hline
\end{tabular}




\begin{tabular}{|c|c|}
\hline Якість & $\begin{array}{l}\text { Конструкції призначені для довгої і надійної експлуатації та зібрані з високоякісних компонентів. } \\
\text { Кроквяні арочні конструкції, виконані з труб, виготовлених з конструкційної сталі, зберігають } \\
\text { свою міцність і структурну цілісність у будь-яких кліматичних умовах, що забезпечує міцність і } \\
\text { надійність споруди. Для північних територій при виготовленні конструкцій використовується } \\
\text { морозостійка сталь марки 09Г2С. Покриття з високоміцної тканої мембранної плівки практично } \\
\text { не вимагають догляду і стійкі до будь-яких видів ушкоджень. }\end{array}$ \\
\hline $\begin{array}{l}\text { Стійкість до } \\
\text { протікань }\end{array}$ & $\begin{array}{l}\text { У покрівлі металевих конструкцій використовуються тисячі кріплень, які з часом послаблюють ії. } \\
\text { Це означає, що тут є тисячі отворів і швів, через які вода може проникати всередину будівлі, а } \\
\text { повітря - назовні. Тент є повністю непроникним для повітря і води, завдяки чому будівля надійно } \\
\text { захищена від протікання і просочування води. Всі конструкції оснащені цільними тентами, всі } \\
\text { поздовжні з’єднувальні шви мають подвійний нахліст і повністю герметичні, при цьому система } \\
\text { натягування тенту розташована всередині будівлі. Каркасно-тентові конструкції є “на } 200 \% \\
\text { більше герметичними”, ніж традиційні будівлі. }\end{array}$ \\
\hline Стійкість до корозії & $\begin{array}{l}\text { На відміну від металевих дахів, тентові покриття не схильні до корозії під впливом води і повітря. } \\
\text { При використанні в жорстких корозійних умовах (наприклад, при зберіганні солі або розташу- } \\
\text { ванні в безпосередній близькості від солоної води) наші конструкції мають довший термін екс- } \\
\text { плуатації. }\end{array}$ \\
\hline Швидкість збірки & $\begin{array}{l}\text { Всі конструкції призначені для збірки з готових модулів і відрізняються швидкістю збірки. } \\
\text { Термін зведення споруди площею } 1500 \mathrm{M}^{2}-\text { близько двох тижнів. Ангари шириною до } 30 \text { метрів } \\
\text { можуть встановлюватися без фундаменту, просто на асфальто-бетонне покриття, за технологією } \\
\text { анкерного кріплення. }\end{array}$ \\
\hline
\end{tabular}

3 метою зниження споживання електроенергії на потреби опалення, економії коштів на електроенергію ми пропонуємо обладнати систему опалення каркасно-тентових ангарів іншим джерелом теплопостачання - тепловим насосом.

Підставою для виконання зазначених робіт є такі нормативно-правові акти:

- Закон України “Про енергозбереження" № 79/94ВР від 01.07.1994;

- ДСТУ 2155-93 “Енергозбереження. Методи визначення економічної ефективності заходів енергозбереження";

- ДСТУ 2339-94 “Енергозбереження. Основні положення";

- ДБН В.2.5-67:2013 “Опалення, вентиляція та кондиціонування";

Технічні характеристики:

- Тип теплової установки - тепловий насос MYCOND GEYZER MHWCH 250S або еквівалент;

- Вихідна потужність - 70 кВт;

- Джерело енергії - геотермальне, існуючі електромережі;

- Площа приміщень - 910,9 кв. м.

Основною метою реалізації проекту є забезпечення виконання вимог Розділу 2 ДСанПІН 3.3.2.007-98,
Розділу III "Вимоги до виробничих приміщень”, ДБН В.1.1-7-2002, введеного в дію Постановою Верховної Ради України від 14 жовтня 1992 року № 2695-XII: “Для підприємств, незалежно від форм власності, або фізичних осіб, які відповідно до законодавства використовують найману працю, витрати на охорону праці становлять не менше 0,5 відсотка від фонду оплати праці за попередній рік”.

Техніко-економічні показники впровадження заходу:

\section{1 Регулювання.}

1.1.1 Технічне обгрунтування.

Для зниження витрат електроенергії на опалення на радіаторах необхідно встановити термостатичні клапани 3 розрахунку один клапан на радіатор. Загальна кількість термостатичних клапанів становить 52 шт., за кількістю опалювальних приладів.

Для установки передбачається прийняти клапан термостатичний RA-FN DN15 з термоелементом RASC2 Danfoss.

\subsection{2 Економія коштів}

Розрахункова економія електроенергії за рахунок регулювання наведена в таблиці 3 (при усуненні перевитрат енергоресурсів понад розрахункові).

Таблиця 3

Розрахункова економія електроенергії за рахунок регулювання, кВт·год

\begin{tabular}{lccccccc}
\hline \multirow{2}{*}{\multicolumn{1}{c}{ Показник }} & \multicolumn{9}{c}{ Опалювальний період } \\
\cline { 2 - 7 } & жовтень & листопад & грудень & січень & лютий & березень & квітень \\
\hline Статистичне & 5426 & 13083 & 22868 & 22456 & 22788 & 14813 & 5584 \\
Розрахункове & 1716 & 14542 & 19786 & 21933 & 19220 & 16706 & 2553 \\
Різниця & 3710 & & 3082 & 523 & 3568 & & 3031 \\
Всього & & & 13914 & & \\
\hline
\end{tabular}

При тарифі на електроенергію 193,28 коп. без ПДВ за 1 кВт·год річний прибуток складе:

13914 х 193,28=26,893 тис. грн без ПДВ

2.2. Встановлення теплового насоса

2.2.1. Технічне обгрунтування
Потужність теплового насоса приймається по розрахунковому тепловому навантаженню не менше 49,71 кВт для мінімальної температури в опалювальний період $-20{ }^{\circ} \mathrm{C}$.

Середня температура повітря в приміщеннях приймається $20^{\circ} \mathrm{C}$. 
Витрата тепла на місячне опалення розраховується за середньомісячними температурами в опалювальний період та кількістю днів опалення на місяць.

3 урахуванням споживання тепла на опалення визначаються характерні температури теплоносія в тій, що подає, і зворотній магістралях. Перераховуємо коефіцієнт перетворення теплового насоса залежно від температури подачі.

Для розрахунку коефіцієнта перетворення визначається кількість тепла, вироблена насосом, і витрати електроенергії на іï вироблення за розрахунковий місяць. До цих витрат додається електроенергія на необхідну циркуляцію розсолу в первинному контурі.

Електрична потужність теплового насоса при мінімальному коефіцієнті перетворювання (КП) складе 12,5 кВт.

Об'ємний витрата розсолу визначається через питомий показник - 184 л/кВт. Для максимального розрахункового навантаження - 9,15 м³/год.

Витрати електроенергії на циркуляцію такого обсягу розсолу при опорі 8 м складають близько 0,5 кВт.

Розрахунок економії електроенергії при використанні теплового насоса наведений у таблиці 4.

\section{Таблиця 4}

Розрахунок економії електроенергії при використанні теплового насоса

\begin{tabular}{lccccccc} 
& жовтень & листопад & грудень & січень & лютий & березень & квітень \\
\hline Середньомісячна температура, ${ }^{\circ} \mathrm{C}$ & 10,5 & 3,9 & $-1,2$ & $-3,5$ & $-2,8$ & 2,1 & 9,4 \\
Днів опалення, діб & 6 & 30 & 31 & 31 & 28 & 31 & 8 \\
Тепло на опалення, кВт & 1716 & 14542 & 19786 & 21933 & 19220 & 16706 & 2553 \\
Температура подачі, ${ }^{\circ} \mathrm{C}$ & 45,0 & 51,0 & 56,0 & 58,0 & 57,0 & 53,0 & 46,0 \\
Коефіцієнт перетворення (КП) & 3,5 & 3,0 & 2,6 & 2,4 & 2,5 & 2.8 & 3,4 \\
Витрати е/е на тепловий насос, & 419,9 & 4912,6 & 7664,8 & 8974,5 & 7652,2 & 5961,5 & 752.2 \\
Додаткові витрати на циркуляційний & 72 & 360 & 372 & 372 & 336 & 372 & 96 \\
насос, кВт/міс. & 1152,2 & 9629,1 & 12121,6 & 12958,6 & 11568,2 & 10744,9 & 1800,9 \\
Економія електроенергії, кВт/міс. & & & & 59976 & & & \\
Всього економія електроенергії за & & & & &
\end{tabular}

\subsection{2. Економія коштів}

Економія електроенергії при використанні теплового насоса в грошовому еквіваленті при тарифі на електроенергію 193,28 коп. без ПДВ за 1 кВт.год складе $59976 \times 193,28=115,922$ тис. грн без ПДВ.

2.2.3. Витрати на реалізацію пропозиції (згідно зі стадією П) цю 5

Витрати на реалізацію пропозиції зведені в табли-

\section{Таблиця 5}

Витрати на встановлення теплового насоса

\begin{tabular}{llc}
\hline \multirow{2}{*}{$№$} & \multicolumn{1}{|}{ Назва витрат } & $\begin{array}{c}\text { Вартість, тис. } \\
\text { грн }\end{array}$ \\
\hline 1 & Вартість устаткування & 385,979 \\
2 & Будівельні роботи & 929,112 \\
3 & Інші витрати & 362,216 \\
& Зведена кошторисна вартість & 1677,307 \\
& будівництва, тис. грн з ПДВ: & \\
\hline
\end{tabular}

Термін окупності інвестицій:

$$
\text { То }=\mathrm{Ki} / \mathrm{Ce} \text {, де: }
$$

То - термін окупності, років;

Кі - інвестиційні кошти (зведена кошторисна вартість будівництва), тис. грн;

$\mathrm{Ce}$ - економія коштів від реалізації інвестицій, тис. грн/рік.

$$
\text { То }=1397,76 /(26,893+115,922)=9,8 \text { року }
$$

\section{Висновки}

Сучасне будівництво ангарів для тваринницьких приміщень передбачає використання сучасних техно- логій та матеріалів. Завдяки цьому вдається скоротити терміни виконання робіт, підвищити надійність та довговічність готових об'єктів, зменшити їх остаточну вартість. Облаштування тваринницьких приміщень тепловим насосом дозволить зменшити споживання електроенергії на потреби опалення та зекономити кошти на електроенергію.

\section{References}

Budivnytstvo anhariv karkasno-tentovoho typu [Elektronnyi resurs]. Rezhym dostupu: https://tentovadomivka.com.ua/uk/category/miviroblyayemo/karkasni-sporudi (in Ukrainian).

Fedorenko, I. Ja., \& Sadov, V. V. (2012). Resursosberegajushhie tehnologii i oborudovanie $\mathrm{V}$ zhivotnovodstve: uchebnoe posobie. SPb: Lan' (in Russian).

Gasanova, H. N., \& Kamilova, P. D. (2007). Osvoenie innovacij v sel'skom hozjajstve / H. N. Gasanova, P. D. Kamilova. Jekonomika sel'skohozjstvennyh i pererabatyvajushhih predprijatij, 4, 36-38 (in Russian).

Karkasnyi abo bezkarkasnyi anhar? [Elektronnyi resurs]. Rezhym dostupu: https://tentovadomivka.com.ua/uk/ blog-uk/karkasnij-abo-bezkarkasnij-angar-shhoobrati-yakij-dah-ne-teche (in Ukrainian).

Smirnov, A. A. (2013). Rol' innovacionnoj dejatel'nosti v razvitii jekonomiki regionov. Fundamental'nye issledovanija, 4 (2), 485-489. https://www.fundamentalresearch.ru/ru/article/view?id=31222 (in Russian).

Uteplennia. Pinopoliurean (PPU). Napylennia ta zalyvka. [Elektronnyi resurs]. Rezhym dostupu: http://penopoliuretan.in.ua/?p=145 (in Ukrainian). 